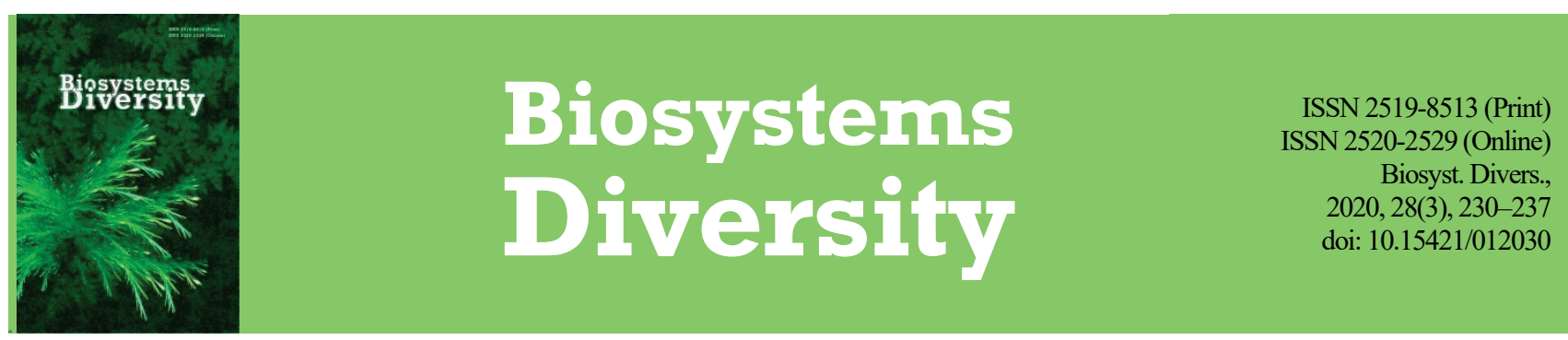

\title{
Morphology, biology and parasite fauna of the least cisco (Coregonus sardinella) of the Yenisei River
}

\author{
Y. S. Nikulina*, K. V. Polyaeva** \\ *National Research Tomsk State University, Tomsk, Russia \\ **Krasnoyarsk Branch of the FSBSI "VNIRO”, Krasnoyarsk, Russia
}

Article info

Received 20.06.2020

Received in revised form 05.08 .2020

Accepted 07.08.2020

National Research

Tomsk State University Lenina st., 36,

Tomsk, 634050, Russia.

Tel.: +7-913-864-45-67.

E-mail:

julianikulina0506@gmail.con

Krasnoyarsk Branch of the FSBSI "VNIRO",

Parizhskoj Kommunyst., 33, Krasnoyarsk, 660049, Russ Tel.: +7-983-150-60-25. E-mail:

glechoma21@gmail.com
Nikulina, Y. S., \& Polyaeva, K. V. (2020). Morphology, biology and parasite fauna of the least cisco (Coregonus sardinella) of the Yenisei River. Biosystems Diversity, 28(3), 230-237. doi:10.15421/012030

In the present study, we present an analysis of the morphological and ecological characteristics of the "turukhanskaja" form of the Siberian least cisco of the Yenisei River, including the characters of the size-age, sexual composition of the population, fecundity and growth. The variability of 34 morphological characters was studied. Significant differences were noted between males and females of the least cisco of the Yenisei River for 11 morphometric characters (head length, maximum body depth, caudal peduncle length, antepectoral distance, dorsal fin base length and dorsal fin depth, anal fin base length, pectoral fin length, head width, head (at nape), interorbital width). Significant differences in meristic characters were revealed in comparison of the least cisco from the Yenisei River with populations of Siberian least cisco from other water bodies. It was shown that the Yenisei least cisco is close to the European vendace Coregonus albula Linnaeus, 1758 not only according to cluster hierarchical analysis for some meristic and morphometric features but also in terms of growth and fecundity. In general, the Yenisei least cisco, as well as other populations of least cisco of the Taimyr, is characterized by heterogeneity in the structure of populations. The parasite fauna of Yenisei's Siberian cisco, captured in the area of Dudinka town, consists of 17 species of parasites from seven systematic groups. It is dominated by Diphyllobothrium ditremum (Creplin, 1825) and Discocotyle sagittata (Leuckart, 1842). The feature of the parasite fauna of least cisco from Yenisei River in comparison with the Ob River (neighbouring water basin) is a low infection with trematodes and a high species diversity of Acanthocephala. The reason for the low infection with trematodes may be differences in the hydrological conditions of the water bodies, which in the Yenisei are unfavourable for the development of intermediate hosts of trematodes. Siberian cisco from the Yenisei River is a carrier of Diphyllobothrium dendriticum (Nitzsh, 1824), a species that can cause human disease.

Keywords: morphological characters; population structure; cluster hierarchical analysis; Neochinorhynchus.

\section{Introduction}

Least cisco Coregonus sardinella Valenciennes, 1848 is a widespread species in river basins of the Arctic and Bering Sea coasts of Northeastern Russia, including the Yenisei River basin (Reshetnikov, 2002). It is an important component of freshwater biocenoses of this vast area. Least cisco is a significant object of industrial, non-industrial (amateur) and ethnic fishing. Like most coregonids, least cisco was able to spread widely within its modern range only in the interglacial and postglacial periods (Podlesnyy, 1958; Dryagin et al., 1969). Despite the relatively short evolutionary time after the last glaciation events (about 20 thousand years), some of the least cisco populations from the northern water bodies of the Krasnoyarsk Territory have a significant differentiation of morphological and ecological features, which makes it difficult to determine their species in some cases (Nikulina et al., 2018). For example, two local anadromous forms of least cisco, namely "turukhanskaja" and "karskaja", live in the Yenisei River (Bobrova, 1958; Ustjugov, 1976). These forms are characterized by significant differences in their morphology and ecology traits. Thus, the forms have different spawning and feeding areas, spawning time and prefer distinct spawning grounds and places. Moreover, "karskaja" and "turukhanskaja" forms of least cisco are differentiated by the time of maturity, the duration of the life cycle, growth rate, and age composition of their populations (Ustjugov, 1972, 1976). In particular, the first form spawns in the Tanama River, the left tributary of the Yenisei River. The Tanama River flows into the Yenisei only $193 \mathrm{~km}$ from its mouth. At the same time, spawning places of the "turuhanskaja" least cisco are located $1,550 \mathrm{~km}$ from its feeding areas. Besides the similarity of a number of vertebrae and some of the morphometric features of the fish-body of the "turuhanskaja" form to the same morphological traits of vendace
(C. albula) is revealed. The number of vertebrae must be a speciesspecific feature for distinguishing C. albula and C. sardinella (Atlas, 2002). It should be noted the least cisco with morphological characters similar to vendace lives also in water bodies of the Norilo-Pyasinskaya hydro-system (lakes Lama, Sobach'je) (Romanov et al., 2016; Borovikova et al., 2018; Nikulina et al., 2018).

Currently, complex data including the results of studies of the morphology, biology, and ecology of the least cisco from the Yenisei River are very sparse and refer to the 1950s and 1960s (Bobrova, 1958; Khodakova, 1971; Ustyugov, 1976).

This work aimed at studying the biology and parasite fauna of modern least cisco of the Yenisei River and make a comparison of our data with information from the literature of the last century for revealing trends of changes in its characteristics. Note that we will discuss data only for the "turuhanskaja" form, since the catching of the "karskaja" form is very difficult at present.

\section{Material and methods}

The "turuhanskaja" form of least cisco were caught in August and September 2016-2017 in the delta area of the Yenisei River near the village of Levinskie Peski ( $69^{\circ} 24^{\prime} 00^{\prime \prime}$ N, $86^{\circ} 11^{\prime} 00^{\prime \prime}$ E, Fig. 1). Morphobiological analysis of the sampled specimens was performed according to methods generally accepted in ichthyology (Pravdin, 1966; Romanov et al., 2016). A total of 245 individuals of least cisco were examined. Fork length (FL), standard length (SL), body weight (W) and body weight without internal organs $(\mathrm{q})$ were measured for each of the specimens. For 118 individuals morphological analysis was performed according to Pravdin's protocol of measurements (1966). Analysis includes 7 meristic 
and 24 morphometric features: number of vertebrae (vt); number of branched rays in dorsal fin $(\mathrm{Db})$, anal fin $(\mathrm{Ab})$, pectoral fin $(\mathrm{P})$, and ventral fin $(\mathrm{V})$; number of lateral line scales (L1); number of gill-rakers on the first left gill arch (Sp.br.); head length (C); maximum body depth (H); maximum body width (B); minimum body depth (h); antedorsal distance (aD); anteventral distance $(\mathrm{aV})$; anteanal distance $(\mathrm{aA})$; antepectoral distance $(\mathrm{aP})$; ventroanal distance (VA); pectroventral distance (PV); caudal peduncle length $(\mathrm{pA})$; dorsal fin base length $(\mathrm{ID})$; dorsal fin depth $(\mathrm{hD})$; anal fin base length (lA); anal fin depth (hA); pectoral fin base length (IP); ventral fin length $(\mathrm{IV})$; snout length $(\mathrm{aO})$; horizontal diameter of eye $(\mathrm{O})$; postorbital distance (pO); head width (bC); head depth through the eye (Ch1); head (at nape) (Ch2); interorbital width (iO). When comparing morphometric characters, we used indices, i.e., the ratios of the measurements to the fork length or head length, rather than absolute values, to compare the parameters of specimens differing in size.

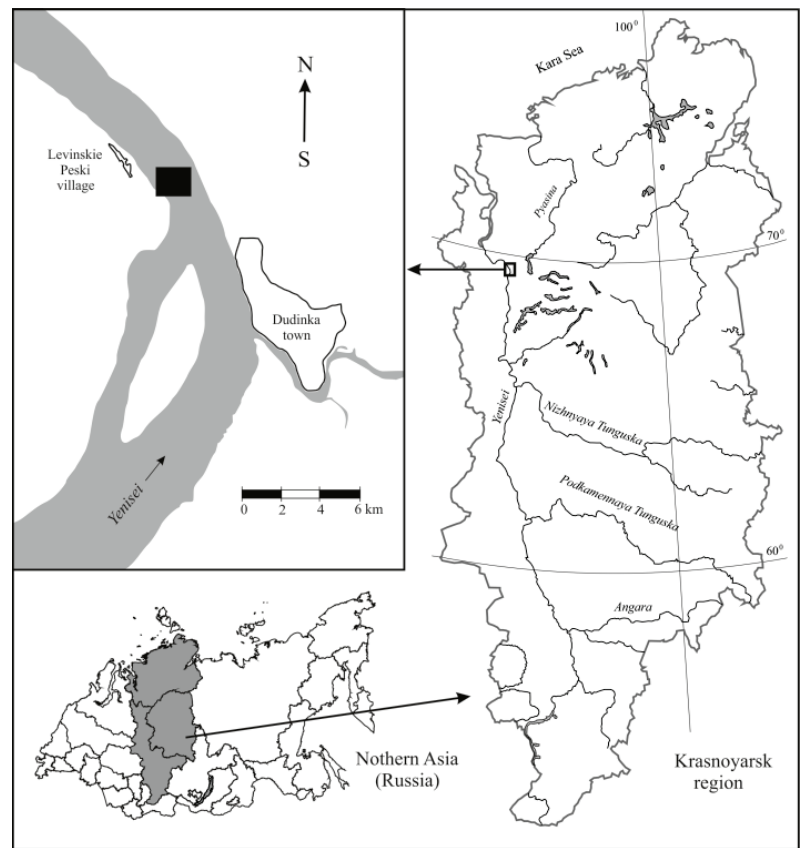

Fig. 1. Map of the study area

The age of the fish was determined using scales according to methodological recommendations of Chugunova (1959). For 49 females, the fecundity was estimated. The individual absolute fecundity was determined using the standard approach. At first, the gonads were weighed. Then a sample of $1 \mathrm{~g}$ was taken from gonads and number of oocytes in the sample was counted. Absolute individual fecundity (AIF) was calculated by multiplying the number of oocytes in the sample of $1 \mathrm{~g}$ by the weight of the ovary (Petlina, 1987). Relative individual fecundity (RIF) was calculated for $1 \mathrm{~g}$ of body weight according to the formula RIF = AIF/W, where W is the weight of the fish (Nikol'ski, 1963; Pravdin, 1966; Romanov et al., 2012).

Least cisco for parasitological analysis were caught in August and September 2010-2013, 2016 in the same area of Levinskie Peski. Complete parasitological analysis (excluding blood parasites and ectoparasitic protozoan) was performed according to the method of ByhovskayaPavlovskaya (1985) on living and fixed by formalin material. A total of 125 least cisco specimens were examined with a fork length of 161-298 (203.7 \pm 2.0$) \mathrm{mm}$ and bodyweight of (Q) 33-193 $(75 \pm 2.5) \mathrm{g}$. The age of the fish ranged from $2+$ to $8+$. Field guides by Bauer $(1984,1985,1987)$ were used for species identification of parasites. Species of Neoechinorhynchus acanthocephalan were determined by the field guide article of Amin (2002) taking into account the comments of Atrashkevich et al. (2016). Parasite systematics and classification are given according to "Checklist of the freshwater fish parasites of the Northern Asia" (Pugachev, 2002, 2003, 2004). Acanthocephala Neochinorhynchus sp. is described like Neochinorhynchus with almost equal in length anterior and middle proboscis, that have roots that extend anteriorly from their bases with apophyses (Atrashkevich et al., 2016).
The data treatment was performed using the Statistica 10 software (StatSoft). During the analysis of morphological data, the mean value of the feature $(x)$ and the standard error $( \pm$ SE) were calculated, the limits of variation (lim) were determined. The obtained series of indicators for morphological features were checked for compliance with the normal distribution. If the distribution of values did not deviate from the normal distribution, the significance of differences in the means for a particular feature was evaluated using Student's t-test. If a significant deviation from the normal distribution was observed, the nonparametric Mann-Whitney test $(\mathrm{U})$ was used. The significance of differences in frequency data was evaluated using the $\chi^{2}$ criterion. To identify the relationship between the characteristics we used correlation analysis. Statistical analysis of parasite infection was carried out using the program Quantitative Parasitology 3.0 (Rozsa et al., 2000).

The cluster hierarchical analysis using the Statistica 10 was performed for classification of least cisco populations. During this analysis, we used our data about "turukhanskaja" form as well as literature data about morphological features of $C$. sardinella of other Siberian waterbodies. In cluster analysis 17 meristic characters and ratios of plastic parameters to fork length were included: number of vertebrae (vt); the number of branched rays in dorsal and anal fins ( $\mathrm{Db}, \mathrm{Ab}$ ), the number of lateral line scales (L.1.); the number of gill-rakers on the first left gill arch (Sp.br.); as ratios to fork length: anterodorsal, anteroventral, anteanal distances $(\mathrm{aD}$, $\mathrm{aA}, \mathrm{aV}$ ), dorsal and anal fins depth and dorsal and anal fins' base length (ID, lA, hD, hA), pectoral and ventral fins length (IP, IV), maximum body depth $(\mathrm{H})$, minimum body depth (h), head length (C). We did not use for analysis the features which were not assessed for all specimens or for which we did not find information in the literature.

\section{Results}

The main 34 meristic and morphometric (plastic) characters of the "turukhanskaja" form of least cisco of the Yenisei River are shown the tables 1 and 2. The specimens with fork length 155-232 mm and bodyweight of 34-127 g represented the basis of the spawning part of this population. During the collection period, we noted a statistically significant predominance of males over females $\left(\chi^{2}=37.77, \mathrm{df}=1, \mathrm{P}<0.001\right)$. A study of the linear-weight characteristics of the fish showed that the females and males of the "turukhanskaja" form were not significantly different from each other. The fork length of males was 155-247 mm (average 185.3 \pm 0.91 ), the fork length of females was 160-243 mm (average 193.6 \pm 1.68$)$; the bodyweight of males was 32-146 g (57.1 \pm $1.02)$ and the bodyweight of females was $34-152 \mathrm{~g}(67.7 \pm 2.22)$.

\section{Table 1}

Meristic characters of $C$. sardinella from the Yenisei,

Kolyma, Pechora rivers $(\mathrm{x} \pm \mathrm{SE})$

\begin{tabular}{lcccc}
\hline Characters & $\begin{array}{c}\text { The Yenisei } \\
\text { River, } \mathrm{n}=118 \\
\text { our data }\end{array}$ & $\begin{array}{c}\text { The Kolyma } \\
\text { River, } \mathrm{n}=145 \\
\text { (Novikov, 1966) }\end{array}$ & $\begin{array}{c}\text { The Pechora River, } \\
\mathrm{n}=41 \text { (Tumanov et } \\
\text { al., 2013) }\end{array}$ & $\begin{array}{c}\text { Lake Ladogala } \\
\mathrm{n}=50 \\
\text { (Dyatlov, } \\
\text { 2002) }\end{array}$ \\
\hline$D b$ & $9.3 \pm 0.06$ & $9.7 \pm 0.05$ & $9.3 \pm 0.10$ & $9.3 \pm 0.11$ \\
$P$ & $13.7 \pm 0.08$ & - & $14.5 \pm 0.11$ & - \\
$V$ & $9.9 \pm 0.06$ & - & $10.3 \pm 0.08$ & - \\
$A b$ & $12.3 \pm 0.07$ & $12.2 \pm 0.08$ & $11.5 \pm 0.12$ & $10.4 \pm 0.14$ \\
L.l. & $71.6 \pm 0.63$ & $83.8 \pm 0.48$ & $72.1 \pm 0.69$ & $77.5 \pm 0.82$ \\
Sp.br. & $45.5 \pm 0.29$ & $41.1 \pm 0.20$ & $43.4 \pm 0.35$ & $40.2 \pm 0.29$ \\
$v t$ & $57.9 \pm 0.10$ & $61.3 \pm 0.13$ & $58.6 \pm 0.21$ & $55.4 \pm 0.19$ \\
\hline
\end{tabular}

Note: data on meristic signs of C. albula are given for comparison; $\mathrm{n}$ - number of specimens; designations of the features are given in Material and methods.

Sexual dimorphism was also found for some other features of external morphology of the "turukhanskaja" least cisco (Table 2). Significant differentiation was revealed for 11 morphometric characters. Females had greater caudal peduncle lengths than males, greater head length and width, longer base lengths of dorsal, anal, and pectoral fins. They also had a higher body, dorsal fin, and head (at the nape). Males, however, are distinguished by a larger antepectoral distance and interorbital width. 
Table 2

Morphometric characters of least cisco of the Yenisei (2016-2017)

\begin{tabular}{|c|c|c|c|c|c|c|}
\hline \multirow{2}{*}{ Characters } & \multirow{2}{*}{$\begin{array}{c}\text { Males, } n=63 \\
\mathrm{x} \pm \mathrm{SE}\end{array}$} & \multirow{2}{*}{$t_{\mathrm{st}}$} & \multirow{2}{*}{$\begin{array}{c}\text { Females, } \mathrm{n}=54 \\
\mathrm{x} \pm \mathrm{SE}\end{array}$} & \multicolumn{2}{|c|}{ Males \& Females, $\mathrm{n}=118$} & \multirow{2}{*}{$\mathrm{CV}, \%$} \\
\hline & & & & $\min -\max$ & $\mathrm{x} \pm \mathrm{SE}$ & \\
\hline$F L, \mathrm{~mm}$ & $189.3 \pm 1.02$ & - & $188.8 \pm 2.33$ & $155-232$ & $189.0 \pm 1.19$ & 6.92 \\
\hline$S L, \mathrm{~mm}$ & $175.8 \pm 1.00$ & - & $175.7 \pm 2.13$ & $145-213$ & $175.7 \pm 1.11$ & 6.94 \\
\hline$Q, g$ & $60.4 \pm 1.22$ & - & $63.7 \pm 2.74$ & $34-127$ & $61.8 \pm 1.42$ & 24.79 \\
\hline$C^{d}$ & $18.4 \pm 0.10$ & 2.78 & $18.8 \pm 0.11$ & $16.6-21.0$ & $18.6 \pm 0.07$ & 0.07 \\
\hline$H^{l}$ & $18.0 \pm 0.12$ & 3.29 & $18.7 \pm 0.18$ & $15.4-21.8$ & $18.4 \pm 0.11$ & 0.11 \\
\hline$B^{l}$ & $9.0 \pm 0.07$ & - & $9.1 \pm 0.10$ & $7.2-11.1$ & $9.1 \pm 0.06$ & 0.06 \\
\hline$p A^{I}$ & $12.0 \pm 0.11$ & 2.08 & $12.4 \pm 0.15$ & $10.2-14.9$ & $12.2 \pm 0.09$ & 0.09 \\
\hline$h^{l}$ & $6.4 \pm 0.04$ & - & $6.5 \pm 0.06$ & $5.5-7.5$ & $6.5 \pm 0.04$ & 0.03 \\
\hline$a A^{I}$ & $67.8 \pm 0.13$ & - & $67.7 \pm 0.19$ & $64.3-70.6$ & $67.8 \pm 0.11$ & 0.11 \\
\hline$a V^{l}$ & $42.8 \pm 0.15$ & - & $42.8 \pm 0.15$ & $40.3-45.3$ & $42.8 \pm 0.11$ & 2.7 \\
\hline$a D^{l}$ & $40.7 \pm 0.13$ & - & $40.4 \pm 0.18$ & $35.9-43.2$ & $40.5 \pm 0.11$ & 2.90 \\
\hline$a P^{l}$ & $17.6 \pm 0.10$ & 2.25 & $17.0 \pm 0.13$ & $15.9-20.0$ & $17.8 \pm 0.08$ & 4.81 \\
\hline$P A^{l}$ & $51.4 \pm 0.16$ & & $51.4 \pm 0.24$ & $47.1-55.4$ & $51.4 \pm 0.14$ & 2.88 \\
\hline$P V^{l}$ & $25.6 \pm 0.16$ & - & $25.6 \pm 0.19$ & $22.1-30.0$ & $25.6 \pm 0.12$ & 5.19 \\
\hline$V A^{l}$ & $26.0 \pm 0.17$ & - & $25.8 \pm 0.23$ & $20.1-29.0$ & $25.9 \pm 0.14$ & 5.73 \\
\hline$I D^{l}$ & $10.0 \pm 0.09$ & 2.43 & $10.5 \pm 0.18$ & $8.2-16.4$ & $10.3 \pm 0.10$ & 10.50 \\
\hline$h D^{l}$ & $15.0 \pm 0.11$ & 3.41 & $15.6 \pm 0.14$ & $13.5-18.3$ & $15.2 \pm 0.09$ & 6.28 \\
\hline$l A^{l}$ & $12.0 \pm 0.08$ & 3.28 & $12.5 \pm 0.14$ & $10.2-16.8$ & $12.2 \pm 0.08$ & 7.33 \\
\hline$h A^{I}$ & $11.1 \pm 0.11$ & - & $11.07 \pm 0.14$ & $8.5-13.5$ & $11.1 \pm 0.08$ & 8.60 \\
\hline$l P^{l}$ & $15.8 \pm 0.11$ & 4.26 & $16.5 \pm 0.13$ & 13.9-18.6 & $16.2 \pm 0.09$ & 6.07 \\
\hline$l V^{A}$ & $16.9 \pm 0.13$ & - & $16.9 \pm 0.11$ & $14.7-21.7$ & $16.9 \pm 0.09$ & 5.79 \\
\hline$a O^{2}$ & $21.2 \pm 0.23$ & - & $20.7 \pm 0.30$ & $16.7-26.5$ & $20.9 \pm 0.19$ & 9.66 \\
\hline$O^{2}$ & $28.4 \pm 0.24$ & - & $28.5 \pm 0.25$ & $23.5-32.4$ & $28.5 \pm 0.17$ & 6.63 \\
\hline$p O^{2}$ & $50.0 \pm 0.35$ & - & $49.2 \pm 0.33$ & $43.2-59.4$ & $49.6 \pm 0.24$ & 5.33 \\
\hline$b C^{2}$ & $39.4 \pm 0.28$ & 2.13 & $40.2 \pm 0.28$ & $35.1-46.9$ & $39.7 \pm 0.20$ & 5.50 \\
\hline$C h_{1}^{2}$ & $49.8 \pm 0.33$ & - & $49.8 \pm 0.38$ & $42.9-56.3$ & $49.8 \pm 0.25$ & 5.43 \\
\hline $\mathrm{Ch}_{2}^{2}$ & $65.1 \pm 0.46$ & 2.65 & $66.8 \pm 0.47$ & $57.6-78.0$ & $65.9 \pm 0.33$ & 5.50 \\
\hline$i O^{2}$ & $23.9 \pm 0.23$ & 7.80 & $20.9 \pm 0.30$ & $17.6-28.1$ & $22.5 \pm 0.23$ & 10.99 \\
\hline$V A^{3}$ & $64.0 \pm 0.50$ & - & $64.0 \pm 0.57$ & $51.3-71.8$ & $64.0 \pm 0.37$ & 6.35 \\
\hline
\end{tabular}

Note: 1 - as $\%$ of fork length; 2 - as $\%$ of head length; 3 - as $\%$ of antedorsal distance; $\mathrm{n}$ - number of specimens, $\mathrm{x} \pm \mathrm{SE}$ - standard error of mean value, min - minimal value of a character, max - maximal value of a character, $\mathrm{SD}$ - standard deviation, $\mathrm{CV}$ - coefficient of variation, $\mathrm{t}_{\mathrm{st}}$ - Student's t-test; designations of the features are given in Material and methods.

Six age groups $(3+-8+)$ were presented in our samples. Specimens of groups $3+-6+$ were more numerous, older individuals were scarce. The least cisco is a short-cycle species; individuals aged $3+(24.5 \%)$ and $4+(49.0 \%)$ years dominated in the spawning shoal. Older age groups $7+$ and $8+$ years old were few (less than $3 \%$ ). The average age of the investigated population was 4.2 years (females 4.3 years, males 4.1 years). It should be noted that males were numerous in the age groups of four$(3+)$ and five-year-old (4+) fish. Females were the dominant group in the other ages. On the whole, males predominated in numbers in the "turukhanskaja" least cisco population: the sex ratio in our catches was $2.3: 1.0$, or $69.4 \%$ of males and $30.6 \%$ of females.

The growth of the body size and weight of the "turukhanskaja" least cisco of our samples is shown in Figure 3. Comparison of the growth characters of this form and C. sardinella of other water bodies revealed that the "turukhanskaja" least cisco is characterized by the slowest growth among them. However, this form grows faster than C. albula from Lake Ladoga. Absolute individual fecundity (AIF) of the "turukhanskaja" least cisco varied 1729-8477 eggs (mean value of this parameter is 3872 eggs), and relative individual fecundity (RIF) ranged 24.7-88.6 eggs per gram of body weight (mean value is 59.0, Table 3 ). We revealed a high positive correlation of age of the females and their fecundity $(\mathrm{r}=+0.72)$.

In the examined individuals of $C$. sardinella 17 species of parasites were found, belonging to different systematic groups: Myxosporidia - 1, Monogenea - 1, Cestoda - 4, Trematoda - 2, Nematoda - 2, Acanthocephala-5, Arthropoda-2 (Table 4).

Table 3

Size and fecundity of "turukhanskaja" least cisco and Coregonus albula (for comparison)

\begin{tabular}{|c|c|c|c|c|c|c|c|c|}
\hline \multirow{2}{*}{ Year } & \multirow{2}{*}{ Age } & \multirow{2}{*}{$\mathrm{N}$} & \multirow{2}{*}{ Fork length, mm } & \multirow{2}{*}{ Weight, $\mathrm{g}$} & \multicolumn{2}{|c|}{ Absolute individual fecundity } & \multicolumn{2}{|c|}{ Relative individual fecundity } \\
\hline & & & & & $\mathrm{x}$ & lim & $\mathrm{x}$ & lim \\
\hline \multirow{3}{*}{$2016-2017$} & $3+$ & 6 & 183 & 56 & 3261 & $2657-3914$ & 58 & $46-68$ \\
\hline & $4+$ & 27 & 192 & 65 & 3667 & $1729-4760$ & 57 & $25-73$ \\
\hline & $5+$ & 9 & 201 & 73 & 4895 & $3181-8477$ & 66 & $48-89$ \\
\hline \multirow{7}{*}{ Ustyugov, 1972} & $3+$ & 3 & 149 & 42 & 3612 & $2140-4636$ & 85 & $72-114$ \\
\hline & $4+$ & 55 & 160 & 45 & 4930 & $2875-5293$ & 118 & $94-129$ \\
\hline & $5+$ & 38 & 168 & 50 & 5814 & $3216-7270$ & 117 & $98-128$ \\
\hline & $6+$ & 12 & 172 & 57 & 8403 & $4010-9720$ & 147 & $116-162$ \\
\hline & $7+$ & 6 & 188 & 68 & 9140 & $6920-16760$ & 135 & $105-140$ \\
\hline & $8+$ & 1 & 194 & 90 & 11716 & - & 131 & - \\
\hline & $9+$ & 1 & 218 & 134 & 11865 & - & 78 & - \\
\hline \multirow{7}{*}{ Dyatlov, 2002} & $1+$ & 32 & 86 & 6.1 & 720 & - & 95 & - \\
\hline & $2+$ & 38 & 104 & 10.9 & 1024 & - & 98 & - \\
\hline & $3+$ & 34 & 124 & 17.5 & 1306 & - & 78 & - \\
\hline & $4+$ & 13 & 138 & 24.8 & 2233 & - & 90 & - \\
\hline & $5+$ & 15 & 157 & 38.9 & 3445 & - & 97 & - \\
\hline & $6+$ & 7 & 178 & 59.6 & 6163 & - & 104 & - \\
\hline & $7+$ & 1 & 179 & 61.5 & 7957 & - & 129 & - \\
\hline
\end{tabular}

Note: $\mathrm{N}$-number of specimens, $\mathrm{N}$ is the absolute number of fish and as $\%$ in parentheses; $\mathrm{M}$ is the mean value; lim is the interval of variation. 
Table 4

Parasitofauna of "turukhanskaja" least cisco in the Lower Yenisei River, 2010-2013, 2016

\begin{tabular}{lcccccc}
\hline \multicolumn{1}{c}{ Species of parasite } & Prevalence, $\%$ & $\begin{array}{c}\text { Confidence } \\
\text { interval of preva- } \\
\text { lence }(95 \%)\end{array}$ & $\begin{array}{c}\text { Mean intensity, } \\
\text { spec. }\end{array}$ & $\begin{array}{c}\text { Confidence inter- } \\
\text { val of mean inten- } \\
\text { sity (95\%) }\end{array}$ & $\begin{array}{c}\text { Mean abundance, } \\
\text { spec. }\end{array}$ & $\begin{array}{c}\text { Confidence inter- } \\
\text { val of mean abun- } \\
\text { dance }(95 \%)\end{array}$ \\
\hline Henneguya zschokkei (Gurley, 1894) & 7.1 & $3.71-12.47$ & 4.73 & $2.36-10.91$ & 0.34 & $0.13-0.99$ \\
Discocotyle sagittata (Leuckart, 1842) & 68.0 & $47.98-83.86$ & 3.71 & $2.47-5.59$ & 2.52 & $1.48-4.04$ \\
Diphyllobothrium dendriticum (Nitzsh, 1824) pl. & 16.1 & $10.86-22.84$ & 1.84 & $1.40-2.52$ & 0.30 & $0.18-0.46$ \\
D. ditremum (Creplin, 1825) pl. & 80.6 & $73.60-86.20$ & 5.11 & $4.27-6.20$ & 4.12 & $3.43-5.08$ \\
Eubothrium crassum (Bloch, 1779) & 1.3 & $0.23-4.69$ & 1.00 & - & 0.01 & $0.00-0.03$ \\
Triaenophorus crassus (Forel, 1868) pl. & 10.3 & $6.37-16.06$ & 1.31 & $1.06-1.88$ & 0.14 & $0.07-0.23$ \\
Crepidostomum farionis (Muller, 1780) Luhe, 1909 & 4.5 & $2.14-9.23$ & 1.29 & $1.00-1.57$ & 0.06 & $0.02-0.11$ \\
Ichthyocotylurus sp. mtc. & 2.6 & $0.89-6.36$ & 6.75 & $4.00-10.25$ & 0.17 & $0.05-0.48$ \\
Cystidicola farionis Fischer, 1798 & 1.3 & $0.23-4.69$ & 1.00 & - & 0.01 & $0.00-0.30$ \\
Philonema sibirica (Bauer, 1946) & 1.0 & $6.64-17.01$ & 5.35 & $3.41-8.18$ & 0.59 & $0.30-1.05$ \\
Echinorhynchus salmonis Muller, 1784 & 38.7 & $31.26-45.48$ & 2.88 & $2.22-3.92$ & 1.12 & $0.79-1.59$ \\
E. truttae Schrank, 1788 & 3.9 & $1.70-8.27$ & 2.33 & $1.00-4.83$ & 0.09 & $0.03-0.29$ \\
E. sp. & 8.4 & $4.70-13.79$ & 1.62 & $1.08-2.54$ & 0.14 & $0.06-0.25$ \\
Neoechinorhynchus salmonis Ching, 1984 & 25.8 & $19.28-33.26$ & 3.22 & $2.22-5.43$ & 0.83 & $0.52-1.46$ \\
N. sp. & 1.9 & $0.53-5.67$ & 1.33 & $1.00-1.67$ & 0.03 & $0.00-0.06$ \\
Salmincola strigatus \& Salmincola extensus* & 32.0 & $16.14-50.02$ & 2.00 & $1.25-3.38$ & 0.64 & $0.28-1.40$ \\
\hline
\end{tabular}

Note: A dash (-) indicates that the confidence interval cannot be calculated; * - the data only for 2016.

Three species of detected parasites were ectoparasites. D. sagittata inhabits the gill filaments of least cisco, $S$. strigatus and $S$. extensus inhabit the ventral and pectoral fins. Fourteen species of detected parasites were endoparasites. Diphyllobotriids encyst on the pyloric caecum and stomach. T. crassus and H. zschokkei encysts inside muscular tissue. Acanthocephala infest the intestine. C. farionis infest the intestine swim bladder. Ichthyocotylurus sp. encysts on the heart's surface.

Least cisco is a definitive host for six species of detected parasites (D. sagittata, C. farionis, E. salmonis, N. salmonis, S. strigatus, S. extensus). Cestodes $D$. dendriticum, $D$. ditremum and trematode Ichthyocotylurus sp. mature in the intestine of fish-eating birds. Cestoda $T$. crassus matures in the intestine of pike Esox lucius Linnaeus, 1758 and is host-specific to it.

The parasite fauna of the analyzed least cisco was dominated by D. ditremum and $D$. sagittata.

Monogenean $D$. sagittata is host-specific to coregonids and salmonids. It has a direct life cycle. Diphyllobothrium cestoda species have copepods as a paratenic host in their life cycles. Cercaria Ichthyocotylurus has an endogenous route into the host fish. Its paratenic hosts are gastropods. Nematode $C$. farionis is host-specific for salmonids. Its paratenic hosts are amphipods. Cestode $T$. crassus has an indirect life cycle: the first intermediate host is copepods, the second is whitefish and grayling, and the definitive is pike.

\section{Discussion}

Features of inter- and intrapopulation morphological diversity of least cisco C. sardinella. Comparison of the meristic traits' mean values of the "turukhanskaja" least cisco and C. sardinella and C. albula of other populations revealed significant differences at the highest level $(\mathrm{P}<0.001)$ for a majority of the compared characters (Table 1).

The most important meristic feature for the least cisco and vendace species identification is the number of vertebrae (Reshetnikov, 1980). The mean number of vertebrae of the "turukhanskaja" least cisco of our samples is 58. This is atypical for least cisco, which is known as a multivertebral cisco: the mean value of the number of vertebrae for this species is often more than 60 (Reshetnikov, 2002). Thus, according to this character, the "turukhanskaja" least cisco is closely related to the vendace. However, the "turukhanskaja" least cisco is not the only least cisco population with the number of vertebrae smaller than it must be according to species diagnosis. C. sardinella with the number of vertebrae less than 59 inhabits rivers and lakes of the Yenisei and Pyasina basins, and lakes of the Transbaikal region (Scrjabin, 1979; Romanov, 2000, 2004; Romanov et al., 2016; Borovikova et al., 2018; Nikulina et al., 2018). It should be noted that the average number of vertebrae becomes smaller with increasing degree of isolation of lake groups (Lake Sobachye - 57; Lake Keta 58; Lake Baunt - 53) from migratory Siberian cisco. Also, low-vertebral Siberian cisco is characterized by fewer scales in the lateral line, which is noted not only for the "turukhanskaja" form of Siberian cisco from the Yenisei but also for Siberian cisco of other river basins: Khatanga, Khantayka (Luk'yanchikov, 1967; Romanov, 2000, 2004).

According to the mean values of another species-specific feature of C. sardinella and C. albula, namely the ratio of the anterodorsal distance to fork length (Reshetnikov, 2002), the "turukhanskaja" least cisco is C. sardinella. It should be noted, however, that in the population under consideration specimens with values of this feature typical for C. albula were registered.

There are no reliable distinguishing features for the identification of two species of least cisco, therefore, one should agree with the wellknown point of view that there is only one species of least cisco in Russia (Dryagin et al., 1969). However, additional research is needed for unambiguous conclusions on this issue. In particular, research on the "karskaja" form of least cisco from the Yenisei is needed.

Cluster hierarchical analysis also showed the similarity of the "turukhanskaja" least cisco with C. albula: this form was included in the same group with vendace from Lake Ladoga. The results of cluster hierarchical analysis including the "turukhanskaja" least cisco and C. sardinella and C. albula of eight other populations are presented in Figure 2. Analysis was performed using five meristic and 12 plastic features. Two groups of cisco populations were revealed. The first group includes the least cisco of the Yenisei ("turukhanskaja" least cisco) and Pechora rivers, of Lake Sobach'je (Putorana Plateau), and vendace of Lake Ladoga. The second group is formed only by riverine populations of the $\mathrm{Ob}$, Yenisei ("karskaja" least cisco), Pyasina, Lena, and Khatanga rivers. Least cisco of the Pechora River and Lake Sobach'je were combined in group 1 also. It is interesting that according to results of the molecular-genetic analysis of polymorphism of two mitochondrial DNA (mtDNA) fragments in these Siberian populations haplotypes characteristic for vendace were found (Nikulina et al., 2016; Borovikova et al., 2018; Nikulina, 2019).

These results allow us to discuss and support certain hypotheses about the origin, spreading, and systematic position of $C$. sardinella. Thus, our data are fully consistent with the hypothesis about the origin and spreading of least cisco put forward by Ustyugov (1976). This author suggested the existence of two ancient centres of origin of least cisco which spread into the borders of the modern range of this species. One of them was the Lena River basin, from where the East Siberian phylogenetic lineage of least cisco entered secondarily into the Laptev Sea basin, and then into the Khatanga, Yenisei ("karskaja" least cisco), Pyasina, and Ob' rivers, the Taz Estuary and the Khalmyer Bay of the Kara Sea.

The second centre of origin is the Yenisei River basin where the "turukhanskaja" least cisco was formed. This form spread to the south along the Yenisei valley and was able to penetrate lakes within the basin of this river. Perhaps, the origination of the least cisco population of Lake Sobach'e (Norilo-Pyasinskaya hydro-system) is associated with this form. As a result, the Yenisei River was inhabited by two phylogenetic lineages of least cisco. The first lineage had its origin in the Lena River basin and 
gave rise to the "karskaja" form of the Yenisei River. The second lineage, namely the "turukhanskaja" form, originated in Yenisei River basin.

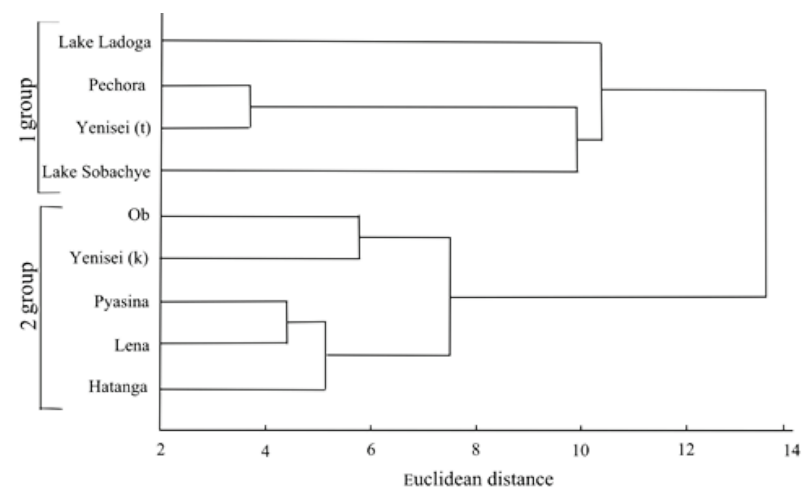

Fig. 2. Dendrogram of morphological similarity of the "turukhanskaja" least cisco of our samples and C. sardinella and C. albula of other populations, constructed using a cluster analysis with 17 morphological parameters: data of literature were used for Esipov (1941), Ol'shanskaya

(1967), Luk'yanchikov (1967), Kirillov (1972), Ustyugov (1972),

Tumanov (2002), Dyatlov (2002), Romanov et al. (2016)

The morphological similarity of the "turukhanskaja" least cisco, as well as least cisco of other Siberian water bodies to C. albula, is apparently due to the similarity of ecological conditions of their habitats. Thus, from the literature it is well known that the number of vertebrae depends on the temperature of the water at which embryogenesis occurs and can increase within the species-area from south to north (Kozhara et al., 1996; Chernyaev, 2007; Etheridge et al., 2012; Borovikova et al., 2013). In most cases, the number of branched rays in the dorsal and anal fins is significantly less in specimens of lacustrine populations, which can be explained by an increase in the area of fins in anadromous forms of cisco (Aleev, 1957). The ability of fish to migrate affects the position of the fins on the body. Thus, lacustrine $C$. albula is less capable of long-distance migrations, and it has larger ventroanal and anterodorsal distances, which indicates a more backward position of ventral and dorsal fins. The anadromous forms of least cisco can perform very long migrations and it has fins shifted to the front of the body (Aleev, 1957; Pokrovskij, 1967).

Thus, there are no morphological features that would demonstrate a clear hiatus between $C$. albula and $C$. sardinella. The data obtained in this study supported the point of view of Dryagin et al. (1969) about the existence in the Eurasian water bodies of a single species of cisco, namely C. albula. However, for unambiguous conclusions about this problem, accurate studies of the morphology and genetic polymorphism of the "karskaja" least cisco of the Yenisei River is needed because this form is considered to be a typical representative of C. sardinella (Kirillov, 1972; Ustyugov, 1972; Nikulina et al., 2018).

Biological features of the "turukhanskaya" least cisco. "Turukhanskaja" least cisco aged $8+$ years were caught in the middle of the XX century (Bobrova, 1958; Ustyugov, 1972). The age of the "turukhanskaja" least cisco spawning shoal in our catches does not exceed this value. An analysis of the size-age structures of adult least cisco (Fig. 3, 4) showed that the length and weight of the "turukhanskaja" least cisco from the Yenisei at the age of $3+$ years were significantly greater $(\mathrm{P}<$ 0.001) than this form of least cisco of the same age in the 1960s (Bobrova, 1958). Comparison of "turukhanskaja" least cisco caught in spawning grounds of the Yenisei (Ustyugov, 1972) with our data and with the data of Bobrova (1958) also reveals significant differences at the highest level of significance $(\mathrm{P}<0.001)$. The "turukhanskaja" least cisco from spawning grounds differs from the least cisco studied by us in lower values of linear-weight characteristics. It should be noted that the least cisco from the Yenisei River at the beginning of spawning migration (end of JulyAugust) is much larger and well-nourished, and in later catches (September) is smaller (Ustyugov, 1972).

At the same time, a comparative analysis of the growth rate of least cisco of Siberian water bodies shows that "turukhanskaya" least cisco is characterized by the slowest growth rate among them. However, this form grows faster than C. albula of the Lake Ladoga (Fig. 4).
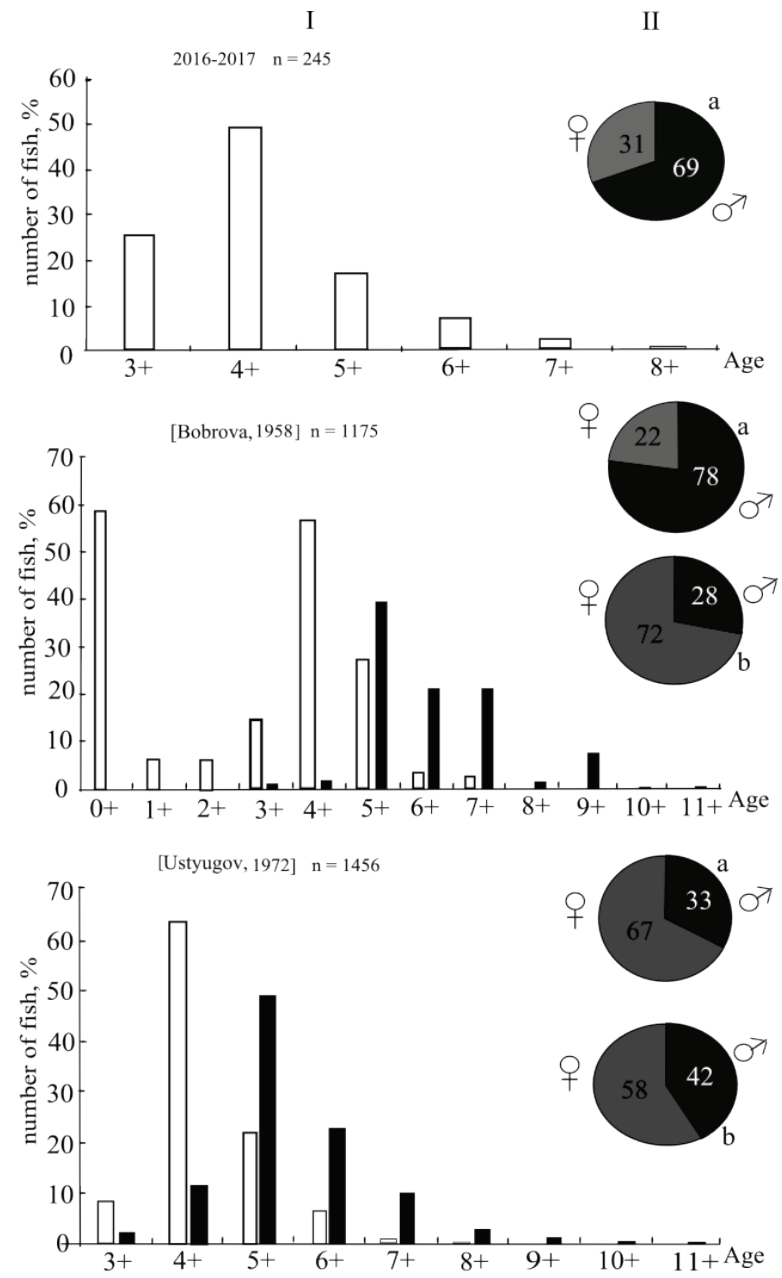

Fig. 3. Structure of the spawning stock of least cisco of the Yenisei River basins: I - age structure; II - sex ratio, \%; the y-axis is the relative number of fish; the x-axis is age; white - "the turuhanskaya" form $(a)$, black - "the karaskaja" form $(b)$

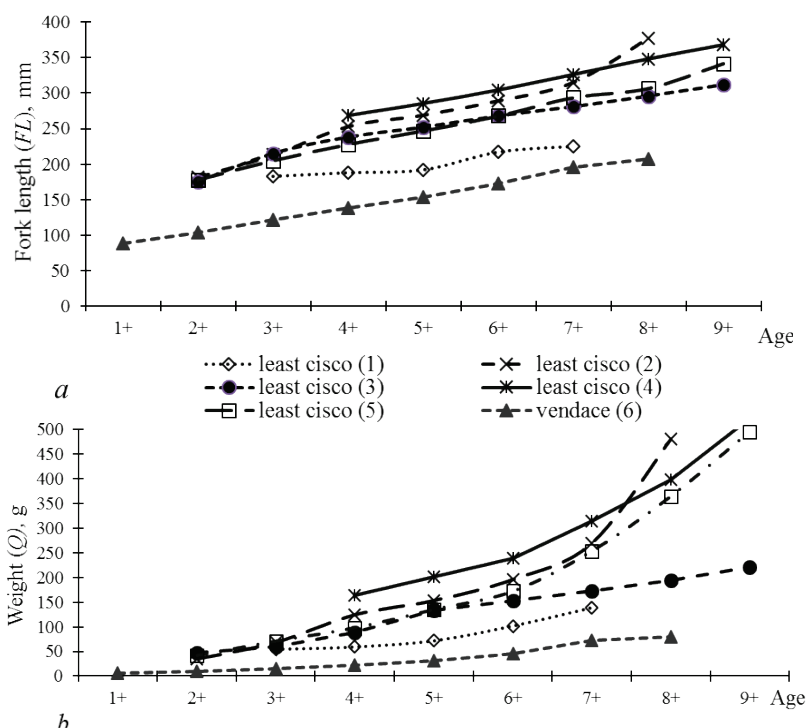

Fig. 4. The growth of body size $(a)$ and weight $(b)$ of the the "turukhanskaja" least cisco in comparison with C. sardinella and $C$. albula of other water bodies: in parentheses is information about the source of the data:

1 - our data; 2 - Ol'shanskaya (1967); 3 - Luk'yanchikov (1967);

4-Kirillov (1955); 5 - Vyshegorodtsev (1971); 6 - Dyatlov (2002) 
The least cisco is an early breeding whitefish. It becomes sexually mature in mass in 3+-4+ years in the Ob, in 4+-6+ years in the Pyasina (Ol'shanskaya, 1967), in 5+-7+ years in the Khatanga (Luk'yanchikov, 1967), mainly in 5+-7+ years in Yakutia's rivers (Kirillov, 1972). Maturation of individuals of the "turukhanskaya" least cisco from the Yenisei does not occur simultaneously in all fish in a certain year of life. As usual, these are males, making up no more than $10 \%$ of the population. Mass maturity occurs on the 5th year (4+) and the proportion of such individuals in the population is already more than $60 \%$. Cases of becoming sexually mature are also known in the 6th year of life (5+). According to the data of 2016-2017, the "turukhanskaya" least cisco becomes sexually mature at the age of $2+$ years (males) singly and in 1-2 years later in mass. The sex ratio in the spawning shoal varies from a significant predominance of males at the beginning of the spawning run to a slight excess of the number of females at the end of the spawning run.

A study of the sexual composition of the "turukhanskaya" least cisco showed that the sex ratio is shifted toward the predominance of males (Fig. 2). The number of males and females can vary while maintaining a ratio close to 1.0:1.5 as a whole in different years or seasons, in different age and size groups. Similar results were noted for the "turukhanskaya" least cisco in the 1950s (Bobrova, 1958) when the sex ratio was estimated as 1.0:3.5. At the same time, another publication (Ustyugov, 1972) considered the spawning shoal of the "turukhanskaya" least cisco from the Yenisei, in which females predominated (58\%). Females predominate in the spawning shoal of the "karskaja" least cisco.

Six age groups were noted with a maximum age of $8+$ in the research catches of the "turukhanskaya" least cisco for 2016-2017 (Fig. 2). According to Ustyugov (1972), the maximum age of least cisco was 8+ in the middle of the last century, which is the limit for this form. The ratio of age groups in the "turukhanskaya" least cisco population is variable. However, the basis of catches is still usually four-year-olds fishes. Com- parison of the morphological traits of males and females of the "turukhanskaja" least cisco revealed significant differences in 11 parameters. It is known from the literature that sexual dimorphism in the external morphology of least cisco is caused by a higher growth rate of females (Esipov, 1941; Pirozhnikov, 1955; Bobrova, 1958; Novikov, 1966; Ustyugov, 1972, 1976). It should be noted, however, that these differences consist in fractions of one percent and can be detected only for statistically significant samples. Thus, the morphological differences between males and females of the "turukhanskaya" least cisco are expressed very slightly. In general, it is believed that in C. sardinella, sexual dimorphism is not expressed (Reshetnikov, 1980).

In our recent work, we compared modern data about morphometric characters of the "turukhanskaya" least cisco and data from the 1950 1960s. Comparison showed that currently least cisco is characterized by longer pectoral and ventral fins and lower in height dorsal fin (Nikulina et al., 2018). These features allow specimens of the modern population to increase their ability to make long migrations (Aleev, 1957).

Absolute and relative fecundity of least cisco from the Yenisei (our data) is much smaller compared with the data of the mid-XX century (Table 3). However, it exceeds absolute fecundity characteristics of the small form of vendace from Lake Ladoga. However, variations of the value of this parameter are very high in each age group. In addition, AIF is strongly dependent on the body size of fish. These facts are true not only for "turukhanskaya" least cisco, but also for $C$. sardinella of other Siberian rivers (Pirozhnikov, 1955; Lukyanchikov, 1967; Vyshegorodtsev, 1971).

Parasite fauna of the "turukhanskaya" least cisco. The detected parasite species are the usual species for least cisco from the Lower Yenisei (caught on the territory of Levinskie Peski village). Common parasites of C. sardinella from the Lower Yenisei, the Lower Ob and Lake Ladoga are monogenean D. sagittata, cestodes of genus Diphyllobothrium, trematodes of genus Ichthyocotylurus and nematode C. farionis (Table 5).

\section{Table 5}

Extensity of invasion of C. sardinella in the Lower Yenisei, the Lower Ob and Lake Ladoga

\begin{tabular}{|c|c|c|c|c|}
\hline \multirow[b]{2}{*}{ Species } & \multicolumn{4}{|c|}{ Water body and prevalence $(\%)$} \\
\hline & $\begin{array}{l}\text { Yenisei (our data), } \\
\text { 2010-2013, 2016 }\end{array}$ & $\begin{array}{c}\text { Yenisei } \\
\text { (Bauer, 1948) }\end{array}$ & $\begin{array}{l}\text { Inflowing streams of Ob } \\
\text { (Gavrilov, 2019) }\end{array}$ & $\begin{array}{c}\text { Lake Ladoga } \\
\text { (Rumyantsev et al., 2001) }\end{array}$ \\
\hline Dermocystidium salmonis Davis, 1947 & - & - & 5.0 & - \\
\hline Henneguya zschokkei (Gurley, 1893) & 7.1 & - & 10.0 & 2.0 \\
\hline Myxidium salvelini Konovalov et Schulman, 1966 & - & - & - & 7.0 \\
\hline Chloromyxum coregoni Bauer, 1948 & - & - & - & 27.0 \\
\hline Discocotyle sagittata (Leuckart, 1842) & $68.0^{*}$ & 12.0 & 10.0 & 40.0 \\
\hline Diphyllobothrium dendriticum (Nitzsh, 1824) & 16.1 & 100.0 & 5.0 & - \\
\hline D. ditremum (Creplin, 1825) & 80.6 & - & 100.0 & 13.0 \\
\hline Cyathocephalus truncatus (Pallas, 1781) & - & - & 5.0 & - \\
\hline Triaenophorus crassus (Forel, 1868) & 10.3 & - & 40.0 & 27.0 \\
\hline Proteocephalus exiguus La Rue, 1911 & - & 6.0 & - & 80.0 \\
\hline Eubothrium crassum (Bloch, 1779) & 1.3 & 12.0 & - & - \\
\hline E. salvelini Schrank, 1790 & - & - & - & 7.0 \\
\hline Crepidostomum farionis (Muller, 1780) Luhe, 1909 & 4.5 & 6.0 & - & - \\
\hline Diplostomum pseudobaeri Razmashkin, Andrejuk, 1978 & $\begin{array}{l}4.5 \\
-\end{array}$ & $\begin{array}{c}0.0 \\
-\end{array}$ & - & 40.0 \\
\hline D. spathaceum (Rudolphi, 1819) & - & - & - & 40.0 \\
\hline D. helveticum (Dubois, 1929) & - & - & 5.0 & + \\
\hline Tylodelphys clavata (Nordmann, 1832) Diesing, 1850 & - & - & - & + \\
\hline Phyllodistomum conostomum (Olsson, 1876) Looss, 1902 & - & 6.0 & - & 13.0 \\
\hline Ichthyocotylurus erraticus (Rudolphi, 1809) Odening, 1969 & - & 18.0 & 100.0 & 60.0 \\
\hline Ichthyocotylurus sp. & 2.6 & - & - & - \\
\hline Camallamus lacustris (Zoega, 1776) & - & - & - & 7.0 \\
\hline Cystidicola farionis Fischer, 1798 & 1.3 & 12.0 & 5.0 & 20.0 \\
\hline Philonema sibirica (Bauer, 1946) & 11.0 & 6.0 & - & - \\
\hline Raphidascaris acus (Bloch, 1779) & - & - & - & 13.0 \\
\hline Echinorhynchus salmonis Muller, 1784 & 38.7 & 75.0 & - & - \\
\hline Echinorhynchus truttae Schrank, 1788 & 3.9 & 6.0 & - & - \\
\hline Echinorhynchus sp. & 8.4 & - & - & - \\
\hline Neoechinorhynchus rutili (Muller, 1780) Stiles et Hassal, 1905 & - & 12.0 & - & - \\
\hline Neoechinorhynchus salmonis Ching, 1984 & 25.8 & - & - & - \\
\hline Neoechinorhynchus sp. & 1.9 & - & - & - \\
\hline Ergasilus sieboldi Nordmann, 1832 & - & - & - & 20.0 \\
\hline Caligus lacustris Steenstrup et Lutken, 1861 & - & - & - & 47.0 \\
\hline Salmincola extensus (Kessler, 1868) & $+*$ & 12.0 & - & - \\
\hline Salmincola strigatus (Markewitsch, 1936) & $+*$ & - & - & - \\
\hline
\end{tabular}

Note: * the data only for 2016.

The monogenean $D$. sagittata has a direct life cycle and can spread without intermediate hosts. It is a parasite species widespread in the Holarctic region. The remaining three parasite species have an indirect life cycle, two of which end their life cycle in organisms existing outside waterbodies. Thus, in all three compared water bodies there are not only intermediate invertebrate hosts of these parasite species, but also their definitive bird hosts, which together form the parasitic system. Least cisco from inflowing streams of the $\mathrm{Ob}$ has the highest rates of infestation of 
Diphyllobothrium cestodes and Ichthyocotylurus trematodes compared to the other water bodies. The prevalence of diphyllobotriids in the Yenisei's least cisco is also high ( $80 \%)$, but the prevalence by Ichthyocotylurus is much lower $(3 \%)$. This could indicate differences in habitat of least cisco in these two watercourses.

The Ob River and its inflowing streams have low flow rates and a well-developed floodplain, which creates optimal conditions for the development of not only zooplankton organisms (intermediate hosts of diphyllobotriids), but also gastropod molluscs (intermediate hosts of trematodes). Least cisco could spend enough time in thickets of aquatic plants, where cercaria of the genus ichthyocotylurus, emerging from the body of molluscs, have the opportunity to attack the fishes and actively invade its circulatory system through the skin.

The Yenisei River has high flow rates which hinders the full development of the zooplankton complex. The "turukhanskaya" least cisco feed on the east coast of Yenisei Bay, where the biomass of food organisms increases faster due to the flow of zooplankton from the lower part of the Yenisei River (Ustyugov, 1972). Also, least cisco does not experience food competition with other fishes. Therefore, the infection rate of "turukhanskaya" least cisco caught in the area of Dudinka is high. At the same time, in the Kara Sea and the river section from the mouth of the Yenisei to Dudinka, favourable conditions for the development of gastropod molluscs probably cannot develop. This may explain the low infection of "turukhanskaya" least cisco with the genus ichthyocotylurus. Also the "turukhanskaya" least cisco completely lacks the complex of eye flukes well developed in the vendace of Lake Ladoga. Eye flukes also use molluscs as the first intermediate hosts. Since the "turukhanskaya" least cisco spends little time in ecosystems favourable for the development of molluscs, it is not attacked by trematode cercariae.

The last of the common species of parasites is $C$. farionis. It has an indirect life cycle in which amphipods take part. In all compared water bodies, the infection with this nematode is low.

Bauer (1948) recorded 14 parasite species in the least cisco caught in the region of Dudinka at the beginning of the XX century. Our research in the region of Dudinka (2010-2013, 2016) revealed three more parasite species. There are microsporidia $H$. zschokkei, cestode $T$. crassus and crustacean S. strigatus. Bauer did not record H. zschokkei and S. strigatus in Yenisei's least cisco. He recorded T. crassus in the region of Igarka (upstream). Of parasites noted by Bauer, we did not find in our collections the cestode $P$. exiguous and trematode $P$. conostomum. Both species had previously low levels of infection (Prev. 6\%).

In 80 years two species have dropped from the list of the least cisco's parasites (both have intermediate hosts in the life cycle) and two new ones arrived with a direct life cycle (H. zschokkei is specific for whitefishes, $S$. strigatus is specific for $C$. sardinella). Thus, species composition of parasites of least cisco from the Yenisei has not undergone significant changes over such a long period.

The parasite fauna of least cisco from inflowing streams of the $\mathrm{Ob}$ consist of 10 parasites species. We noted seven of them for the Yenisei's least cisco. There are no D. salmonis, $T$. crassus and $D$. helveticum parasitising the Yenisei's least cisco.

The parasite fauna of vendace from Lake Ladoga is significantly different from the parasite fauna of least cisco from the Yenisei and the $\mathrm{Ob}$. In Ladoga, the species composition of myxosporidia, trematodes and nematodes is wider, but acanthocephala are completely absent. The similarity of the species composition of Yenisei's least cisco parasites (Jaccard's community coefficient) decreases in a row "the Yenisei in the 1940 s $(0.65)$ - inflowing streams of the $\mathrm{Ob}(0.25)$ - Lake Ladoga (0.20)".

The crustacean $S$. strigatus is a host-specific parasite for least cisco. Its geographic range is the rivers $\mathrm{Ob}$ and Yenisei and Lake Baikal (Pugachev, 2004). S. extensus is host-specific for whitefish.

\section{Conclusion}

As a result of the study of "the turuhanskaya" sympatric form of Siberian cisco from the Yenisei River, characters of morphology, ecology and parasitology of this population were revealed. Studies of diagnostic characters of these Siberian cisco and the data presented in the literature allow us to consider that the structure of Siberian cisco from the Taimyr water bodies is heterogeneous. So, according to only a species-specific trait (the number of vertebrae), the studied Siberian cisco is low-vertebral and can be classified as C. albula. Cluster hierarchical analysis of morphometric and meristic characters also showed the proximity of Siberian cisco from the Yenisei river to vendace.

The comparison of Siberian cisco from the Yenisei with other Siberian cisco populations from Siberia and the vendace population from Lake Ladoga revealed a relatively low growth rate of the Siberian cisco from the Yenisei. It reaches sizes close to the size of Siberian cisco at the age of two years in large water bodies of Siberia (the Yuribey, the Pyasina, the Khatanga, the Indigirka) only at the age of 3-4 years. Absolute fecundity characteristics of the Yenisei's Siberian cisco are also lower than characteristics of other compared Siberian cisco, however, it exceeds the mean value of fecundity of the small form vendace from Lake Ladoga. Based on data on the nature of mature vendace (Dyatlov, 2002), it can be concluded that the vendace from Lake Ladoga and the Siberian cisco from the Yenisei (our data) have a reproductive ability higher than the other compared groups of Siberian cisco from Siberia. Maturation of the vendace from Lake Ladoga occurs at the age of two to three years, the "turuhanskaya" Siberian cisco reach the state of puberty in the fourth year of life (3+ years). This is earlier than typical Siberian cisco (5+-6+ years). This fact also brings the Yenisei's Siberian cisco closer to C. albula.

The parasite fauna of the Yenisei's Siberian cisco, captured in the area of Dudinka, consists of 17 species of parasites. It is dominated by $D$. ditremum and $D$. sagittata. The composition of the parasite fauna has undergone minor changes over 80 years. Two parasite species with an indirect life cycle noted earlier by researchers are no longer recorded in the studied population of Siberian cisco, which may indicate a decrease in the number or a disappearance of their intermediate hosts. Of the two previously unrecorded parasite species, one has a direct life cycle, i.e. does not need an intermediate host, one has an indirect life cycle. Both species are specific for whitefish. The feature of the parasite fauna of Yenisei's Siberian cisco in comparison with that of the Ob River (neighbouring river basin) is a low infection with trematodes and a high species diversity of Acanthocephala. The reason for the low infection with trematodes may be differences in the hydrological conditions of water bodies, which in the Yenisei are unfavourable for the development of intermediate hosts of trematodes. Siberian cisco from the Yenisei River is a carrier of $D$. dendriticum, a species that can cause human disease.

The authors thank N. O. Yablokov (Krasnoyarsk Branch of FSBI "VNIRO") for assistance in creating the map; T. G. Burdukovskaya (Institute of General and Experimental Biology SB RAS) and E. I. Mikhailova (Institute of Biological Problems of the North FEB RAS) for help with the species identification of parasites.

The article was prepared with financial support of the Ministry of Education and Science, Russia within the state assignment No 0721-2020-0019.

\section{References}

Aleev, Y. G. (1957). Kharakteristika i topografiya funktsiy plavnikov ryb [Characteristics and topography of fish fin functions]. Voprosy Ikhtiologii, 8, 55-76 (in Russian).

Amin, O. M. (2002). Revision of Neoechinorhynchus Stiles \& Hassal, 1905 (Acanthocephala: Neoechinorhynchidae) with keys to 88 species in two subgenera. Systematic Parasitology, 53(1), 1-18.

Atrashkevich, G. I., Miahjlova, E. I., Orlovskaja, O. M., \& Pospehov, V. V. (2016). Bioraznoobrazie skrebnej ryb presnyh vod Aziatskoj Subarktiki [Biodiversity of Acanthocephalans (Acanthocephala) in freshwater fishes of Asiatic Sub-Arctic region]. Parazitologiya, 50(4), 263-290 (in Russian).

Bauer, O. N. (1948). Parazity ryb r. Eniseja [Parasites of The Yenisei river's fishes]. Izvestija Vsesoyuznogo Nauchno-Issledovatel'skogo Instituta Ozyornogo i Rechnogo Rybnogo Hozyajstva, 27, 97-156 (in Russian).

Bauer, O. N. (Ed.). (1984). Opredelitel' parazitov presnovodnykh ryb fauny SSSR. T. 1. Paraziticheskie prosteyshie [Field guide for the identification of fish parasites of the USSR's fauna. Vol. 1. Parasitic protozoans]. Leningrad, Nauka (in Russian).

Bauer, O. N. (Ed.). (1985). Opredelitel' parazitov presnovodnykh ryb fauny SSSR. T. 2. Paraziticheskie mnogokletochnye (1-ya chast') [Field guide for the identification of fish parasites of the USSR's fauna. Part 1. Parasitic metazoans]. Leningrad, Nauka (in Russian). 
Bauer, O. N. (Ed.). (1987). Opredelitel' parazitov presnovodnykh ryb fauny SSSR. T. 2. Paraziticheskie mnogokletochnye (2-ya chast') [Field guide for the identification of fish parasites of the USSR's fauna. Part 2. Parasitic metazoans]. Leningrad, Nauka (in Russian).

Bobrova, N. N. (1958). Sibirskaya ryapushka Coregonus sardinella Valenciennes [Cisco Coregonus sardinella Valenciennes]. Izvestiya Izvestija Vsesoyuznogo Nauchno-Issledovatel'skogo Instituta Ozyornogo i Rechnogo Rybnogo Hozyajstva, 44, 179-189 (in Russian).

Borovikova, E. A., Alekseeva, Y. I., Schreider, M. J., Artamonova, V. S., \& Makhrov, A. A. (2013). Morphology and genetics of the ciscoes (Actinopterygii: Salmoniformes: Salmonidae: Coregoninae: Coregonus) from the Solovetsky Archipelago (White Sea) as key to determination of the taxonomic position of ciscoes in Northeastem Europe. Acta Ichthyologica et Piscatoria, 43(3), 183194.

Borovikova, E. A., Romanov, V. I., \& Nikulina, J. S. (2018). Morphological and genetic features of cisco (Coregonidae: Coregonus sp.) from Lake Sobachye (Putorana Plateau). Russian Joumal of Genetics: Applied Research, 8(1), 47-55.

Byhovskaya-Pavlovskaya, I. E. (1985). Parazity ryb. Rukovodstvo po izucheniiyu [Fish parasites. Study Guide]. Nauka, Leningrad (in Russian).

Chugunova, N. I. (1959). Rukovodstvo po izucheniyu vozrasta i rosta ryb [Guide to the study of age and growth of fish]. USSR Academy of Sciences, Moscow (in Russian).

Dryagin, P. A., Pirozhnikov, P. L., \& Pokrovskiy, V. V. (1969). Polimorfizm sigovykh ryb (Coregoninae) i ego biologicheskoe i rybokhozyaystvennoe znachenie [Polymorphism of coregonine fishes and its significant for fishery]. Voprosy Ikhtiologii, 9(1), 14-25 (in Russian).

Dyatlov, M. A. (2002). Ryby Ladozhskogo ozera [Fish of Lake Ladoga]. Karel'skiy Nauchnyy Tsentr RAN, Petrozavodsk (in Russian).

Esipov, V. K. (1941). Ryapushka severnoy chasti Obskoy guby i Gydanskogo zaliva [Cisco of the northern part of the Gulf of $\mathrm{Ob}$ and Gydan Bay]. Trudy Instituta Polyarnogo Zemledeliya, Zhivotnovodstva i Promyshlennogo Hozyajstva, 15, 7-36 (in Russian).

Etheridge, E. C., Adams, C. E., Bean, C. W., Durie, N. C., Gowans, A. R. D., Harrod, C., Lyle, C. W., Maitland, P. S., \& Winfield, I. J. (2012). Are phenotypic traits useful for differentiating among a priori Coregonus taxa? Journal of Fish Biology, 80, 387-407.

Gavrilov, A. L. (2019). Sovremennye dannye o parazitofaune sigovyh ryb v ural'skih pritokah nizhnej Obi [Modem parasitofauna data of whitefishes from the Ural's feeders of the Lower Ob]. Vestnik Syktyvkarskogo Universiteta, Serija Biologija, Geologija, Himija, Jekologija, 3(11), 104-111.

Kirillov, F. N. (1972). Ryby Yakutii [Fish of Yakutia]. Nauka, Moscow (in Russian).

Kozhara, A. V., Izyumov, Y. G., \& Kas'yanov, A. N. (1996). Obshchaya i geograficheskaya izmenchivost' chisla pozvonkov u nekotorykh presnovodnykh ryb [General and geographical variability of the number of vertebrae in some freshwater fish]. Voprosy Ikhtiologii, 36(2), 179-194 (in Russian).

Luk'yanchikov, F. V. (1967). Ryby sistemy reki Khatangi [Fish of the Khatanga River System]. Trudy Krasnoyarskogo Otdeleniya Sibirskogo NauchnoIssledovatel'skogo Instituta Rybnogo Hozyajstva, 9, 11-93 (in Russian).

Nikulina, Y. S. (2019). Filogeografiya ryapushek basseyna Severno-Ledovitogo okeana [Phylogeography of least cisco of the Arctic Ocean Basin]. In: Modern problems and prospects for the development of the fishery complex. Moscow. Pp. 356-360 (in Russian).

Nikulina, Y. S., Borovikova, E. A., \& Budin Y. V. (2018). Morfologicheskaya differentsiatsiya rechnykh i ozernykh populyatsiy ryapushek (Coregonus sp.) basseynov morey Karskogo i Laptevykh [Morphological differentiation of river and lake populations of cisco (Coregonus sp.) from the basins of the Karski and Laptev seas]. Uchenyye Zapiski Rossijskogo Gosudarstvennogo Gidrometeorologicheskogo Universiteta, 51, 162-175 (in Russian).

Nikulina, Y. S., Romanov, V. I., \& Borovikova, E. A. (2016). O sostoyanii fauny ryapushek roda Coregonus ozer plato Putorana (poluostrov Taymyr) i sopredel'nykh territoriy [About fauna of cisco (Coregonus) from lakes of the Putorana Plateau (the Taimyr Peninsula) and adjacent territories]. In: Biology, biotechnology of breeding and the condition of the stocks of white fishes. Tyumen. Pp. 73-74 (in Russian).

Novikov, A. S. (1966). Ryby reki Kolymy [Fish of the Kolyma River]. Nauka, Moskow (in Russian)

Ol'shanskaya, O. L. (1967). Ryapushka sistemy reki Pyasiny [Cisco of the Pyasina River system]. Trudy Krasnoyarskogo Otdeleniya Sibirskogo NauchnoIssledovatel'skogo Instituta Rybnogo Hozyajstva, 9, 94-213 (in Russian).

Pirozhnikov, P. L. (1955). Materialy po biologii promyslovykh ryb reki Leny [Materials on the biology of commercial fish of the Lena River]. Izvestiya Vsesoyuznogo Nauchno-Issledovatel'skogo Instituta Ozernogo i Rechnogo Rybnogo Khozyaystva, 35, 61-128 (in Russian).
Podlesnyy, A. V. (1958). Ryby Yeniseya, usloviya ikh obitaniya i ispol'zovaniya [Fish of the Yenisei, their habitat and use]. Izvestija Vsesoyuznogo NauchnoIssledovatel'skogo Instituta Ozyornogo i Rechnogo Rybnogo Hozyajstva, 44, 97-178 (in Russian)

Pokrovskij, V. V. (1967). O morfologicheskih osobennostyah, proishozhdenii i geograficheskom rasprostranenii belomorskoj ryapushki Coregonus sardinella maris-albi Berg. [About morphological features, origin and geographical distribution Coregonus sardinella maris-albi Berg.]. Izvestia Gosudarstvennogo Nauchno-Issledovatel'skogo Instituta Ozernogo i Rechnogo Rybnogo Hozyajstva, 62, 100-114 (in Russian).

Pravdin, I. F. (1966). Rukovodstvo po izucheniyu ryb [Manual for study of fish]. Pishchepromizdat, Moscow (in Russian).

Pugachev, O. N. (2002). Katalog parazitov presnovodnykh ryb Severnoy Azii. Knidarii, monogenei, tsestody [Checklist of the freshwater fish parasites of the Northern Asia. Cnidaria, Monogenoidea, Cestoda]. Trudy Zoologicheskogo Instituta, Saint Petersburg (in Russian).

Pugachev, O. N. (2003). Katalog parazitov presnovodnykh ryb Severnoy Azii. Trematody [Checklist of the freshwater fish parasites of the Northern Asia. Trematoda]. Trudy Zoologicheskogo Instituta, Saint Petersburg (in Russian).

Pugachev, O. N. (2004). Katalog parazitov presnovodnykh ryb Severnoy Azii. Nematody, skrebni, piyavki, mollyuski, rakoobraznye, kleshchi [Checklist of the freshwater fish parasites of the Northern Asia. Nematoda, Acanthocephala, Hirudinea, Mollusca, Crustacea, Acari]. Trudy Zoologicheskogo Instituta, Saint Petersburg (in Russian).

Reshetnikov, Y. S. (1980). Ekologiya i sistematika sigovykh ryb [Ecology and systematics of the coregonid fishes]. Nauka, Moscow (in Russian).

Reshetnikov, Y. S., Popova, O. A., \& Sokolov, L. I. (2002). Atlas presnovodnykh ryb Rossii [Atlas of Russian freshwater fish]. Nauka, Moscow (in Russian).

Romanov, V. I. (2000). Morfo-ekologicheskaya kharakteristika ryapushki iz ozera Tommot (basseyn r. Khatangi) i nekotorye diskussionnye voprosy sistematiki evraziyskikh ryapushek [Morphoecological characteristics of Coregonus from the Lake Tommot (River Khatanga basin) and some disputable questions of European Coregonus systematics]. Sibirskiy Ekologicheskiy Zhurnal, 7(3), 293304 (in Russian).

Romanov, V. I. (2004). Piscifauna of the Putorana Plateau. In: Fauna pozvonochnykh zhivotnykh plato Putorana [Vertebrate Fauna of the Putorana Plateau]. Moscow. Pp. 29-89 (in Russian).

Romanov, V. I., Petlina, A. P., \& Babkina, I. B. (2012). Metody issledovaniya presnovodnykh ryb Sibiri [Methods of investigating fresh-water fish in Siberia]. Tomskij Gosudarstvennyj Universitet, Tomsk (in Russian).

Romanov, V. I., Zadelenov, V. A., Nikulina, Y. S., \& Polyaeva, K. V. (2016). Morfologiya i parazitologiya ryapushki ozera Sobach'ego (plato Putorana) [Morphology and parasitology of the Sobachye Lake Coregonus albula L. (Plateau Putorana)] Vestnik Novosibirskogo Gosudarstvennogo Agrarnogo Universiteta, 38, 69-77 (in Russian).

Rozsa, L., Reiczigel, J., \& Majoros, G. (2000). Quantifying parasites in samples of hosts. Joumal of Parasitology, 86(2), 228-232.

Rumyantsev, E. A., Shul'man, B. S., \& Ieshko, E. P. (2001). Parazitofauna ryb Ladozhskogo ozera [Parasitofauna of fishes of Lake Ladoga]. In: Ekologo-parazitologicheskie issledovaniya zhivotnykh i rasteniy Evropeyskogo Severa, Petrozavodsk. Pp. 13-24 (in Russian).

Tumanov, M. D. (2002). Osobennosti morfologii, tempa rosta i vozrastnoy struktury poluprokhodnoy i rechnoy form ryapushki Coregonus albula (L.) basseyna r. Pechora [Peculiarities of the morphology, growth rate, and age structure of the semi-aisle and riverine forms of vendace Coregonus albula (L.) in the Pechora River]. In: Vodnyye organizmy $\mathrm{v}$ yestestvennykh i transformirovannykh ekosistemakh Yevropeyskogo Severo-Vostoka. Pp. 137-144 (in Russian).

Tumanov, M. D., Vorobiev, D. S., \& Martynov, V. G. (2013). Sigovyye ryby nizhnego techeniya reki Usy v usloviyakh tekhnogennogo zagryazneniya [The Coregonus species of the River Usa downstream in anthropogenic polluted environment]. Izdatel'stvo Tomskogo Universiteta, Tomsk (in Russian).

Ustyugov, A. F. (1972). Ekologo-morfologicheskaya kharakteristika sibirskoy ryapushki Coregonus albula sardinella (Valenciennis) basseyna reki Yenisey [Ecological and morphological characteristics of the Siberian cisco Coregonus albula sardinella (Valenciennis) of the Yenisei River]. Voprosy Ikhtiologii, 12(5), 811-825 (in Russian).

Ustyugov, A. F. (1976). O proiskhozhdenii dvukh ekologicheskikh form sibirskoy ryapushki Coregonus albula sardinella (Val.) basseyna reki Yenisey [On the origin of two ecological forms of Siberian cisco Coregonus albula sardinella (Val.) in the Yenisei River]. Voprosy Ikhtiologii, 16(5), 773-783 (in Russian).

Vyshegorodtsev, A. A. (1975). Morfologicheskaya kharakteristika sibirskoy ryapushki Coregonus albula sardinella (Val.) r. Yuribey (basseyn Gydanskogo zaliva) [Morphological characteristic of the Siberian cisco Coregonus albula sardinella (Val.) of the Yuribey River (Gydan Bay basin)]. Voprosy Ikhtiologii, 15(1), 32-42 (in Russian). 